\title{
A PRELIMINARY INVENTORY OF SUBTERRANEAN TERMITES IN THE PREMISES OF FACULTY OF SCIENCE, UNIVERSITY OF KELANIYA AND THE POTENTIAL OF A PONERINE ANT SPECIES, NEEMAZAL-F AND CITRONELLA OIL IN THE CONTROL OF TWO TERMITE SPECIES
}

\section{K.H.C.A. WIJERATHNA AND R.K.S. DIAS*}

\section{Department of Zoology, University of Kelaniya.}

\begin{abstract}
Termites are an important biotic component in terrestrial ecosystems and the termites in seven localities of the Faculty of Science of University of Kelaniya were investigated by employing soil sifting, litter sifting, hand collection, baited pitfall trapping and long term baits from September, 2008 to April, 2009. The collected termites were preserved in $80 \%$ ethanol. Soil temperature and $\mathrm{pH}$, and percentage soil moisture at each location were also recorded. Members of Termitidae and Rhinotermitidae, Dicuspeditermes incola Wasmann, Heterotermes ceylonicus Holmgren, Nasutitermes ceylonicus Holmgren, Nasutitermes horni Wasmann, Odontotermes ceylonicus Wasmann, Odontotermes horni Wasmann and Trinervitermes rubidus Hagen, were recorded. Odontotermes horni had a wide distribution in the seven localities. The interactions between a common ponerine ant, Odontomachus simillimus F. Smith and $O$. ceylonicus Wasmann revealed that $O$. simillimus acts as a natural enemy of this termite species. Termiticidal potential of Neemazal-F and citronella oil on the soldiers and workers of $O$. horni was evident while $\mathrm{LD}_{50}$ values were $11.15 \mathrm{mg}$ and $8.21 \mathrm{mg}$ per body weight $\mathrm{g}^{-1}$ of each product, respectively.
\end{abstract}

* Corresponding author Email: rksdias@kln.ac.lk 


\section{K.H.C.A. Wijerathna}

\section{Keywords}

Termites of University premises, citronella oil, Neemazal-F, Odontotermes horni, Odontotermes ceylonicus, Trinervitermes rubidus, Odontomachus simillimus

\section{INTRODUCTION}

Termites (Order: Isoptera) are a very important biotic component on earth as they play a significant role in recycling materials and, act as serious pests of agricultural crops and many other materials (Harris1961; Roonwal \& Chhotani 1989; Pearce 1999; Thakur 2000). Subterranean termites that live in soil or diffused chambers are very destructive pests among them (Harris 1961). The diversity of the world termite fauna is estimated to be of seven families, 282 genera and 2,761 species (Rathore \& Bhattacharyya 2004). Although termites belonging to three families, Kalotermitidae, Rhinotermitidae and Termitidae, twenty seven genera and fifty four species have been recorded from Sri Lanka (Roonwal \& Chhotani 1989; Chhotani 1997) very little is published recently (Hemachandra et al. 2010) on the termites that inhabit different regions of the country.

Termites have a wide range of natural enemies such as insects, birds, reptiles and mammals. Ants (Order: Hymenoptera, Family - Formicidae), specially, the dorylines and ponerines, can cause high mortality in termites (Harris 1961; Pearce 1999). Commercially available insecticides, e.g. Chlorpyrifos, endosulfan, carbofuran and permethrin, are usually applied to control termites that act as pests (Thakur 2000; Pearce 1999) irrespective of their adverse effects on the environment. Natural plant extracts such as neemazal-F and citronella oil also show insecticidal properties and are less harmful to the environment (Pearce 1999; Wijesekara 1973).

The aim of this investigation was to prepare a preliminary inventory of subterranean termites while studying their distribution in the Science Faculty premises of University of Kelaniya and provide information on the effects of neemazal-F and citronella oil on the subterranean termite, Odontotermes horni Wasmann, a known pest of coconut (Harris 1961). Odontomachus simillimus F. Smith is a common ponerine ant species recorded from the Science Faculty premises of University of Kelaniya (Dias 2006) and this paper also presents the 


\section{A Preliminary Inventory of Subterranean Termites}

interactions between this ant species and the subterranean termite, Odontotermes ceylonicus Wasmann under the laboratory conditions.

\section{MATERIALS AND METHODS}

\section{Study sites}

Termites were surveyed in seven regions (A-G) of the Faculty of Science (Figure 1). Site A $\left(06^{0} 58^{\prime} \mathrm{N} 79^{0} 54^{\prime} \mathrm{E}\right)$ is about $500 \mathrm{~m}^{2}$ and situated around building A5. Site B $\left(06^{0} 58^{\prime} \mathrm{N} 79^{\circ} 54^{\prime} \mathrm{E}\right)$ is about $500 \mathrm{~m}^{2}$ and situated behind the Department of Statistics and Computer Science. Site C $\left(06^{0} 58^{\prime} \mathrm{N} 79^{0}\right.$ $\left.54^{\prime} \mathrm{E}\right)$ is about $700 \mathrm{~m}^{2}$ and is the botanical garden of Science Faculty. Site D $\left(06^{0}\right.$ $\left.58^{\prime} \mathrm{N} 79^{\circ} 54^{\prime} \mathrm{E}\right)$ is about $150 \mathrm{~m}^{2}$ and situated behind Sri Dharmaloka Convocation Hall (building A1). Site E $\left(06^{0} 58^{\prime} \mathrm{N} 79^{0} 54^{\prime} \mathrm{E}\right)$ is about $50 \mathrm{~m}^{2}$ and situated behind the Department of Zoology. Site F $\left(06^{0} 58^{\prime} \mathrm{N} 79^{0} 54^{\prime} \mathrm{E}\right)$ is about $150 \mathrm{~m}^{2}$ and a grassland situated behind the Department of Chemistry. Site G $\left(06^{0}\right.$ $58^{\prime} \mathrm{N} 79^{0} 54^{\prime} \mathrm{E}$ ) is about $100 \mathrm{~m}^{2}$ and an open grassland situated behind the building A8.

\section{Field sampling methods}

Table 1 shows the total number of samples collected by each method (Taylor et al. 1998; Pearce 1999) from each site. Termite soldiers, workers and reproductives in each soil sample $\left(20 \times 20 \times 5 \mathrm{~cm}^{3}\right)$ were collected after sifting soil with a sieve and a tray. All individuals were preserved in $80 \%$ ethanol. Plastic cups $(5 \mathrm{~cm} \times 5 \mathrm{~cm} \times 5 \mathrm{~cm})$ were filled with $20 \mathrm{ml}$ of $30 \%$ ethanol and set randomly at a $5 \mathrm{~cm}$ depth with the mouth of the cups flush with the surface soil level. Five traps were set throughout each site and collected after 24 hours. Pieces of decaying wood and unscented toilet paper tissues were placed as baits at each pitfall trap (Taylor et al. 1998).

Litter and decaying pieces of wood carrying mud galleries were collected randomly from each site. Termites were sorted by a pair of forceps and preserved in $80 \%$ ethanol. Sawdust, cattle dung or toilet paper wetted with water was wrapped in an aluminium foil (each of $100 \mathrm{~g}$ ) to make the baits. Holes were made in the foil to facilitate the entry of termites. The bait packs $(n=5)$ were set randomly at a $5 \mathrm{~cm}$ depth on the $26^{\text {th }}$ of September, 2008 and observed after 3 months. 


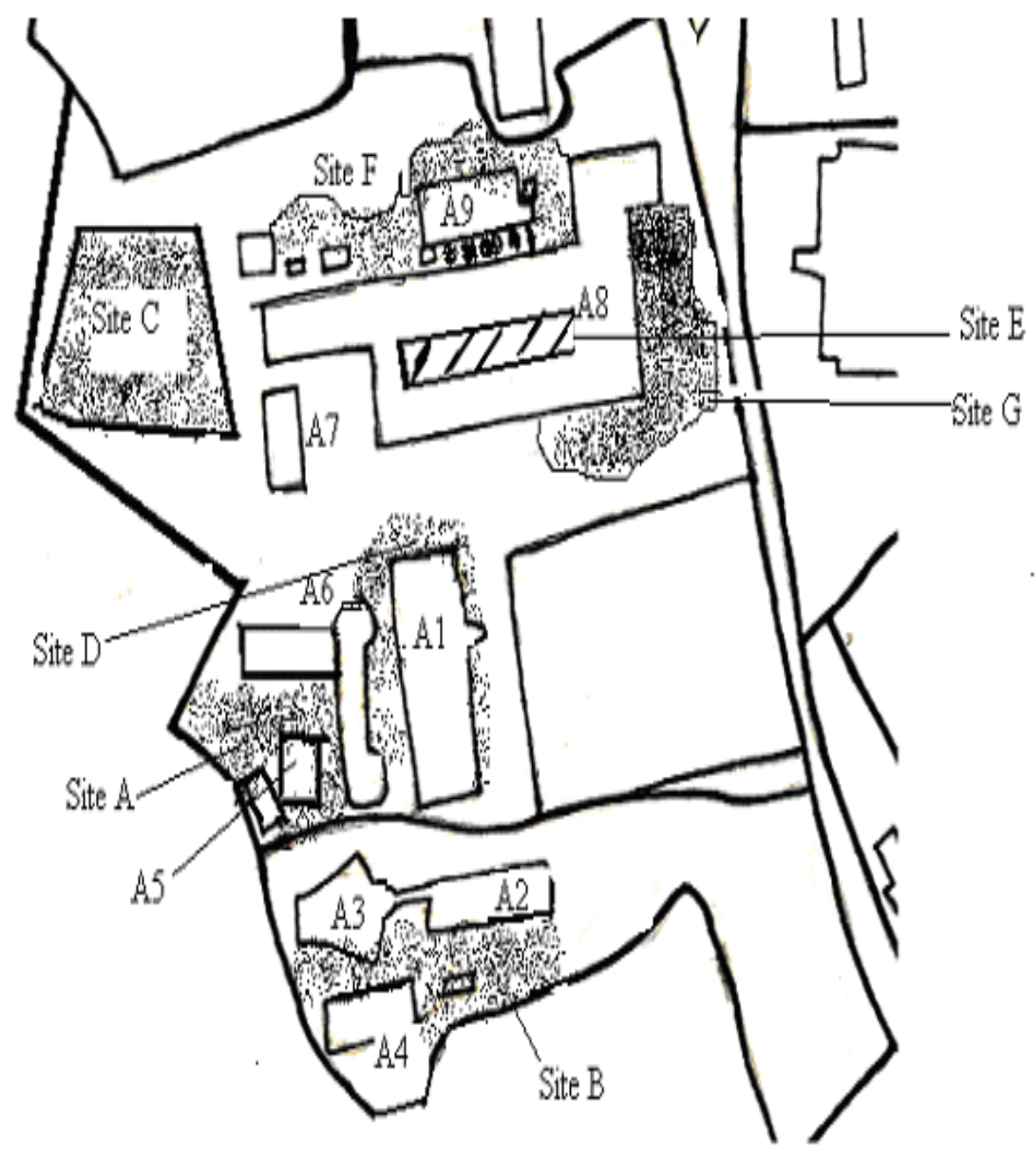

Figure 1: A schematic diagram showing the sites in the premises of Faculty of Science, University of Kelaniya 
Table 1: Total number of samples collected by each method from each site

\begin{tabular}{|c|c|c|}
\hline Region & Sampling method & $\begin{array}{l}\text { Number of samples } \\
\text { taken by each method }\end{array}$ \\
\hline A & $\begin{array}{l}\text { Soil sifting } \\
\text { Litter sifting } \\
\text { Hand collection }\end{array}$ & $\begin{array}{c}25 \\
6 \\
5 \\
\end{array}$ \\
\hline B & $\begin{array}{l}\text { Soil sifting } \\
\text { Litter sifting } \\
\text { Hand collection } \\
\end{array}$ & $\begin{array}{c}15 \\
5 \\
4 \\
\end{array}$ \\
\hline $\mathrm{C}$ & $\begin{array}{l}\text { Soil sifting } \\
\text { Hand collection } \\
\text { Baited pitfall traps }\end{array}$ & $\begin{array}{c}25 \\
6 \\
5 \\
\end{array}$ \\
\hline $\mathrm{D}$ & $\begin{array}{l}\text { Soil sifting } \\
\text { Litter sifting } \\
\text { Baited pitfall traps }\end{array}$ & $\begin{array}{c}10 \\
2 \\
5 \\
\end{array}$ \\
\hline $\mathrm{E}$ & $\begin{array}{l}\text { Soil sifting } \\
\text { Litter sifting } \\
\text { Hand collection }\end{array}$ & $\begin{array}{c}10 \\
2 \\
1 \\
\end{array}$ \\
\hline $\mathrm{F}$ & $\begin{array}{l}\text { Soil sifting } \\
\text { Litter sifting } \\
\text { Hand collection }\end{array}$ & $\begin{array}{c}20 \\
4 \\
2 \\
\end{array}$ \\
\hline G & $\begin{array}{l}\text { Soil sifting } \\
\text { Hand collection } \\
\text { Baited pitfall traps }\end{array}$ & $\begin{array}{c}10 \\
3 \\
5\end{array}$ \\
\hline Building A5 & Long term baits & 4 \\
\hline Building A6 & Long term baits & 4 \\
\hline Building A8 & Long term baits & 4 \\
\hline
\end{tabular}




\section{K.H.C.A. Wijerathna}

\section{Collection of termites from the buildings}

The bait packs $(n=12)$ described previously were set randomly at selected places in the building A5, A6 and A8.

\section{Measurement of environmental parameters}

Soil temperature $(\mathrm{n}=3)$ and $\mathrm{pH}(\mathrm{n}=4)$ at each site were measured using a thermometer and a $\mathrm{pH}$ meter. Percentage soil humidity was estimated by collecting four soil samples, each of $100 \mathrm{~g}$, from each site and keeping them in an oven at $105{ }^{\circ} \mathrm{C}$ for twenty four hours.

Soil moisture $\%=\frac{(\mathrm{A}-\mathrm{B})}{\mathrm{B}} \times 100$

A = Initial weight of the soil sample

$\mathrm{B}=$ Weight of the soil sample after drying at $105^{\circ} \mathrm{C}$ for 24 hours.

\section{Laboratory analysis of termites}

Termites in each sample were identified to the furthest possible taxon under a low power stereo-microscope at suitable magnifications with reference to Roonwal \& Chhotani (1989) and Chhotani (1997). A calibrated micrometer eye piece fixed to a high power microscope at x10 magnification was used to record each measurement. In mandibulate soldiers, total length, head length and width, mandible length, pronotum length and width, length and width of postmentum of individuals were measured. Head index (maximum width of head/ length of head to lateral base of mandibles), mandible-head index (maximum length of mandibles/length of head to lateral base of mandibles), pronotum-head index (maximum width of pronotum/ maximum width of head) were estimated according to Roonwal \& Chhotani (1989). Length of head, length of rostrum and posterior bulge of head of five individuals were measured in non-mandibulate soldiers. Rostrum-head index (length of head rostrum/ length of head without rostrum) was calculated for each soldier termite according to Roonwal \& Chhotani (1989). 


\section{A Preliminary Inventory of Subterranean Termites}

Procedure for studying the interactions between Odontomachus simillimus and Odontotermes ceylonicus

The trials were performed in a regiform structure (Figure 2) that consisted of a larger cavity (diameter: $10 \mathrm{~cm}$ ) and two small cavities (diameter: 5 $\mathrm{cm})$. A $10 \mathrm{~cm}$ long channel connected the three cavities with each other. This structure was dorsally covered with a glass. Soldiers and workers of $O$. simillinus were collected from the Science Faculty premises of University of Kelaniya and kept in a covered plastic basket in the laboratory at a temperature range of 28 - $29{ }^{\circ} \mathrm{C}$. Soldiers and workers of $O$. ceylonicus were collected from the Science Faculty premises on the date of experiment. First, major workers of ants $(n=20)$ were introduced to the larger cavity with colony materials. Soldiers $(n=2)$ and workers $(n=7)$ of termites were introduced to a small cavity with $1 \mathrm{~g}$ of moist soil and a piece of gauze cloth wetted with distilled water. Small cavity at the middle was kept blocked initially with a piece of regiform. The insects were allowed to acclimate for half an hour. The small cavity was unblocked after half an hour and the activities of test insects were observed for eight hours. Two other trials were also conducted and the mortality of termites was recorded after eight hours. Termites which were kept in an ant-free environment served as the control for each trial.

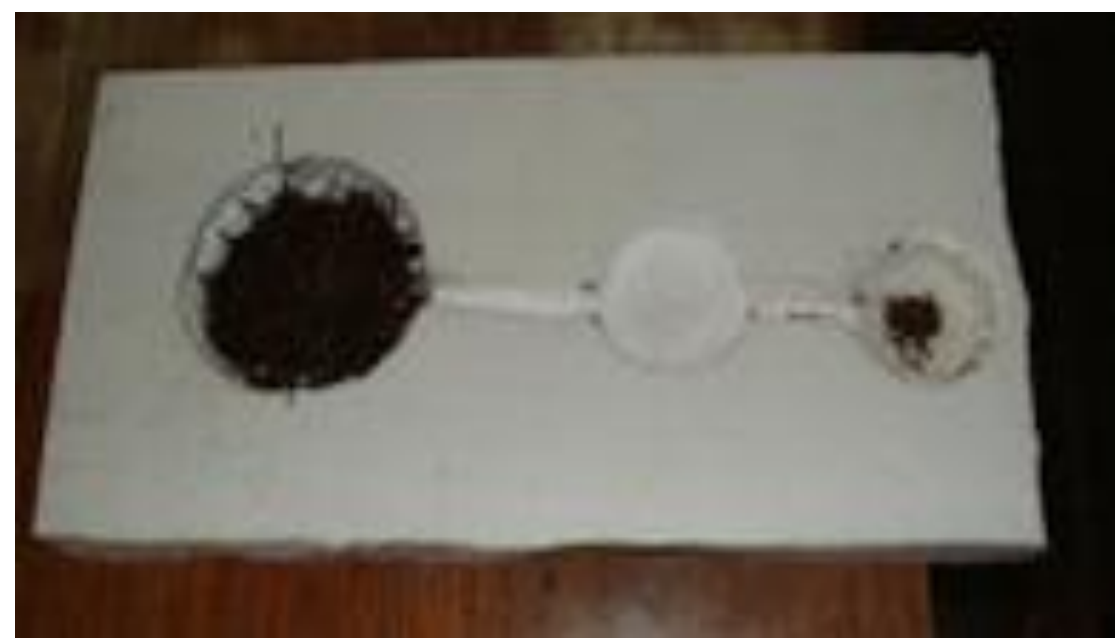

Figure 2: The structure used to study the interaction between $O$. simillimus and $\boldsymbol{O}$. ceylonicus 


\section{K.H.C.A. Wijerathna}

\section{Procedure for testing the effects of citronella oil and Neemazal-F on $O$. horni}

A bottle of citronella oil (100\%) was purchased from Beem Hela Osu Lanka \& Neemazal-F was provided by Islandwide Marketing Service (Pvt) Ltd. Both soldiers and workers of $O$. horni were collected from the Science Faculty premises of University of Kelaniya on the date of experiment. Topical application of each product to ten individuals was carried out by using a microapplicator. A series of volumes of citronella oil $(0.5 \mu 1,1.0 \mu 1,2.0 \mu 1,3.0 \mu 1,4.0 \mu 1$, $5.0 \mu 1$ and $6.0 \mu \mathrm{l})$ and a series of volumes of Neemazal-F $(0.5 \mu 1,0.8 \mu 1,1.0 \mu 1$, $2.0 \mu 1,3.0 \mu \mathrm{l}$ and $4.0 \mu \mathrm{l}$ ) were applied to the prothorax of each termite separately. This experiment was repeated twice with two other sets of termites. Control termites were kept without applying botanical products simultaneously. Time (s) taken by each individual to die after the application of each product was recorded. Numbers of dead termites in each trial were analyzed using Chi-square test with Yates' correction to investigate whether $O$. simillimus acts as a natural enemy of $O$. ceylonicus. Lethal dosage of each product $\left(\mathrm{LD}_{50}\right)$ was estimated by the probit analysis.

\section{RESULTS}

Although several methods were employed soil sifting, direct hand collection and litter sifting were only positive for termites. Soil sifting was successful in collecting termites more often than other methods carried out in each region (Table 2). Termites were not attracted to the baits kept at indoor sites.

Based on the major morphological features and morphometric measurements of soldiers (Table 3), termites belonging to two families, Termitidae and Rhinotermitidae, five genera and seven species were identified (Table 4).

Distribution of termite species in the premises of Science Faculty and the environmental parameters of each locality are shown in Table 5. The most common $O$. horni showed a wide distribution whereas the least common species, T. rubidus was observed at the site G only. 
Interactions between $\boldsymbol{O}$. simillimus and $\boldsymbol{O}$. ceylonicus

Number of dead termites observed in each trial (Figure 3) in the presence of $O$. simillimus was significantly higher than that observed in each control (Chi-square test, $\mathrm{p}<0.05$ ).

\section{Effects of Citronella oil and the Neemazal-F on $O$. horni}

Mean survival time of $O$. horni gradually decreased with the increase of citronella oil volume from $0.5 \mu 1$ to $6 \mu 1$ (Figure 4) and increase of neemazal- F volume from $0.5 \mu 1$ to $4 \mu 1$ (Figure 5). The lethal dosages $\left(\mathrm{LD}_{50}\right)$ of citronella oil and Neemazal-F were $11.15 \mathrm{mg}$ and $8.21 \mathrm{mg}$ per body weight $\mathrm{g}^{-1}$, respectively.

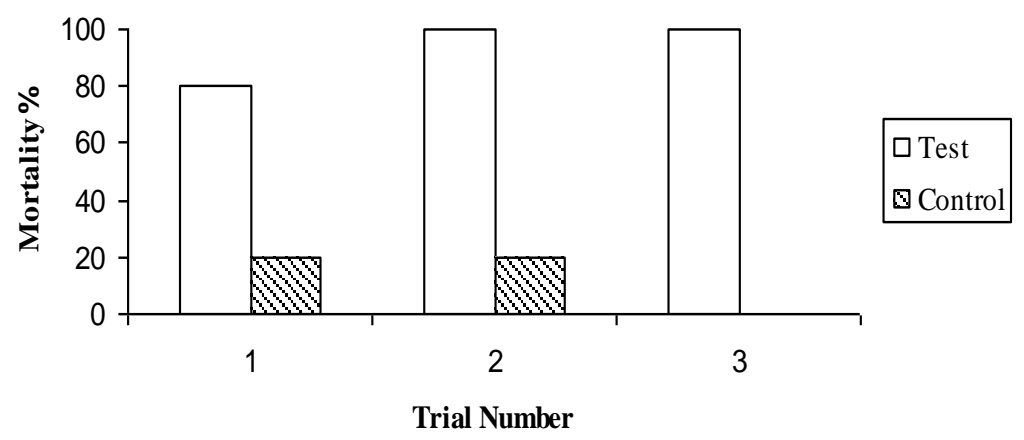

Figure 3: Percentage mortality of termites observed in each trial

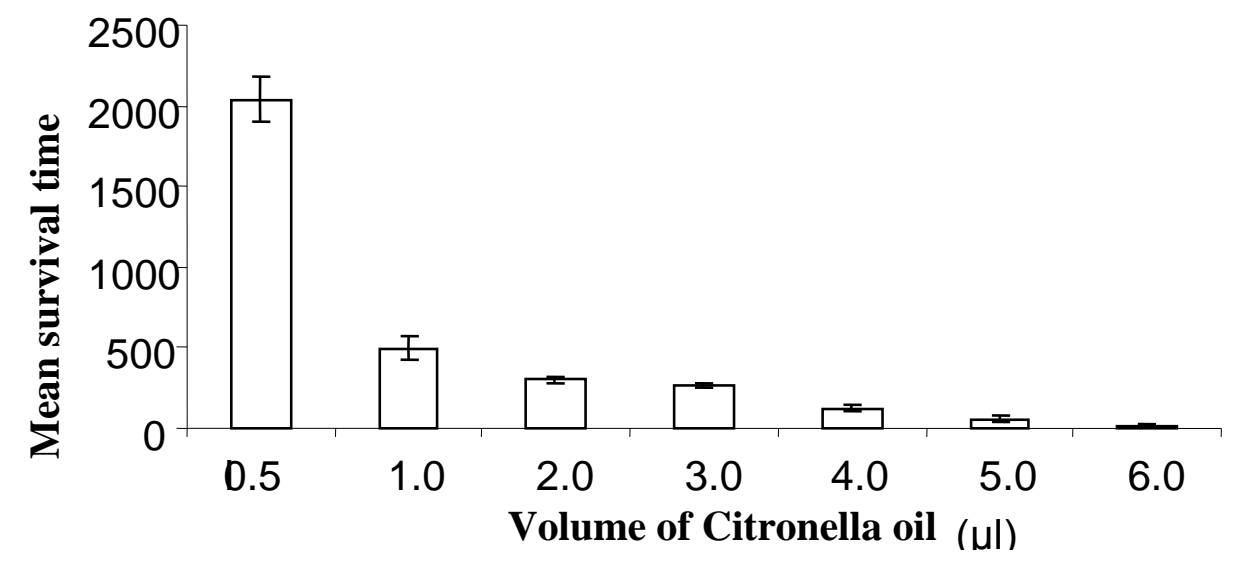

Figure 4: Mean survival time (s) \pm SE of $O$. horni for each volume of citronella oil 


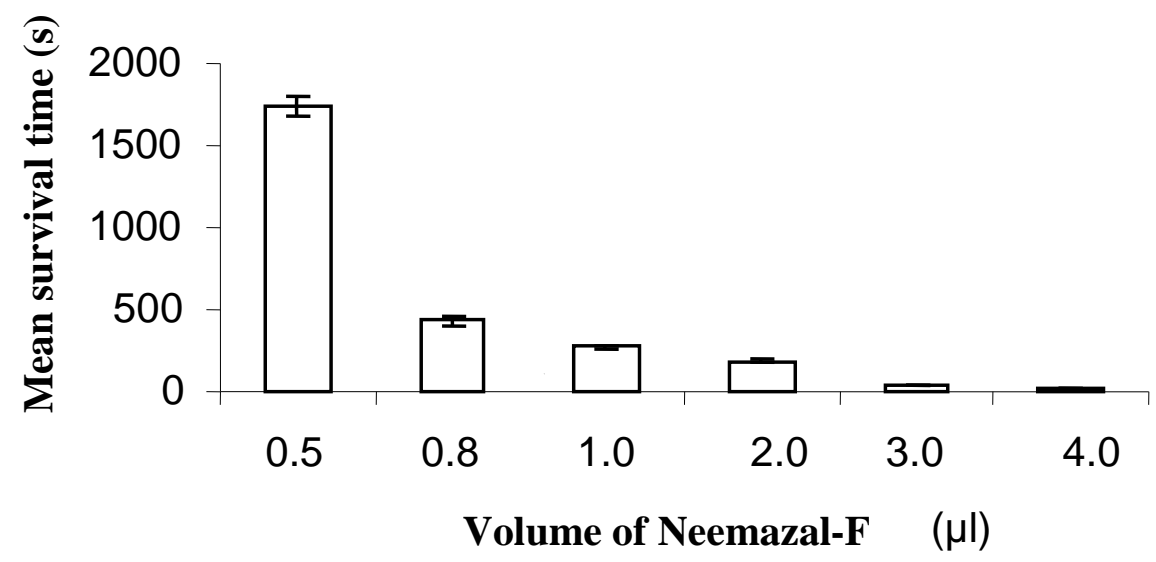

Figure 5: Mean survival time $\pm \mathrm{SE}$ of $O$. horni for each volume of Neemazal-F 
Table 2: Methods that resulted termites and the frequency of occurrence of termites by each method in each region.

\begin{tabular}{|l|l|l|}
\hline Study region & Sampling method & $\begin{array}{l}\text { Frequency of occurrence } \\
\text { of termites (sample wise) }\end{array}$ \\
\hline A & Soil sifting & $10 / 17$ \\
& Litter sifting & $3 / 17$ \\
& Hand collection & $4 / 17$ \\
\hline B & Soil sifting & $7 / 10$ \\
& Litter sifting & $1 / 10$ \\
\hline C & Hand collection & $2 / 10$ \\
\hline D & Soil sifting & $14 / 16$ \\
& Hand collection & $2 / 16$ \\
\hline E & Soil sifting & $5 / 6$ \\
& Litter sifting & $1 / 6$ \\
\hline F & Soil sifting & $4 / 5$ \\
& Hand collection & $1 / 5$ \\
\hline G & Soil sifting & $5 / 7$ \\
& Litter sifting & $1 / 7$ \\
\hline & Hand collection & $1 / 7$ \\
\hline & Soil sifting & $3 / 4$ \\
& Hand collection & $1 / 4$ \\
\hline
\end{tabular}


Table 3: Morphometrics $(\mathrm{mm})$ of the seven termite species identified during this survey

\begin{tabular}{|c|c|c|c|c|c|c|c|c|}
\hline Total length & - & $3.2-3.5$ & $2.9-4.0$ & $3.0-3.8$ & $5.7-5.9$ & $7.0-8.5$ & $4.2-4.3$ & $3.25-3.4$ \\
\hline Head length & $1.75-2.0$ & $1.2-1.25$ & $1.35-1.45$ & $0.8-0.9$ & $1.8-1.9$ & $2.0-2.5$ & $2.25-2.32$ & $1.5-1.6$ \\
\hline Head width & $1.2-1.25$ & $0.75-0.8$ & $0.8-1.8$ & $0.7-1.0$ & $1.38-1.4$ & $2.0-2.15$ & - & $1.4-1.5$ \\
\hline Mandible length & L-1.3-1.45 R-0.97-1.1 & $0.5-0.53$ & - & - & $1.1-1.2$ & $1.4-1.6$ & - & - \\
\hline $\begin{array}{l}\text { Posterior bulge of } \\
\text { head }\end{array}$ & - & - & $0.28-0.30$ & $0.23-0.38$ & - & - & $0.4-0.6$ & $1.75-2.0$ \\
\hline Pronotum length & - & $0.3-0.32$ & $0.18-0.20$ & $0.18-0.22$ & $0.56-0.58$ & $0.75-0.95$ & $3.6-3.75$ & $0.18-0.23$ \\
\hline Post-mentum length & - & $0.75-0.78$ & - & - & $0.8-0.95$ & $1.5-1.75$ & - & - \\
\hline Post-mentum width & - & $0.25-0.3$ & - & - & $0.5-0.6$ & $0.75-0.95$ & - & - \\
\hline Rostrum length & - & - & $0.45-0.5$ & $0.45-0.5$ & - & - & $0.75-0.8$ & $0.6-0.63$ \\
\hline Rostrum head length & - & - & $0.9-1.2$ & $1.25-1.35$ & - & - & $1.45-1.53$ & $1.42-1.5$ \\
\hline Head index-A & $0.6-0.7$ & $0.63-0.64$ & - & - & $0.75-0.8$ & $0.86-1.0$ & - & - \\
\hline Pronotum-head index & $0.37-0.38$ & $0.46-0.50$ & - & - & $0.55-0.6$ & $0.68-0.80$ & - & - \\
\hline Rostrum head index & - & - & $0.42-0.5$ & $0.36-0.37$ & - & - & $0.5-0.52$ & $0.4-0.42$ \\
\hline Species name & $\begin{array}{l}\text { Dicuspeditermes } \\
\text { incola }\end{array}$ & $\begin{array}{l}\text { Heterotermes } \\
\text { ceylonicus }\end{array}$ & $\begin{array}{l}\text { Nasutitermes } \\
\text { ceylonicus }\end{array}$ & $\begin{array}{l}\text { Nasutitermes } \\
\text { horni }\end{array}$ & $\begin{array}{l}\text { Odontotermes } \\
\text { ceylonicus }\end{array}$ & $\begin{array}{l}\text { Odontotermes } \\
\text { horni }\end{array}$ & $\begin{array}{l}\text { Trinervitermes } \\
\text {.rubidus } \\
\text { Soldier major }\end{array}$ & $\begin{array}{l}\text { Trinervitermes } \\
\text { rubidus } \\
\text { Soldier minor }\end{array}$ \\
\hline
\end{tabular}


Table 4: Preliminary inventory of termites (Order: Isoptera) of the Science Faculty premises of University of Kelaniya

\begin{tabular}{|c|c|c|c|}
\hline Family & Genus & Species & Plate No. \\
\hline Rhinotermitidae & Heterotermes & $\begin{array}{l}\text { H. ceylonicus } \\
\text { Holmgren }\end{array}$ & Plate 2 - soldier \\
\hline Termitidae & Dicuspeditermes & $\begin{array}{l}\text { D. incola } \\
\text { Wasmann }\end{array}$ & Plate 1- soldier \\
\hline Termitidae & Nasutitermes & $\begin{array}{l}\text { N. ceylonicus } \\
\text { Holmgren }\end{array}$ & $\begin{array}{l}\text { Plate } 3 \text { - } \\
\text { soldier form } 1 \\
\text { Plate } 4 \text { - } \\
\text { soldier form } 2 \\
\end{array}$ \\
\hline Termitidae & & N. horni Wasmann & $\begin{array}{l}\text { Plate } 5 \text {-soldier } \\
\text { form } 1 \\
\text { Plate } 6 \text { - } \\
\text { Soldier form } 2\end{array}$ \\
\hline Termitidae & Odontotermes & $\begin{array}{l}\text { O. ceylonicus } \\
\text { Wasmann }\end{array}$ & Plate 7 - Soldier \\
\hline Termitidae & Odontotermes & O. horni Wasmann & Plate 8 - soldier \\
\hline Termitidae & Trinervitermes & T. rubidus Hagen & $\begin{array}{l}\text { Plate } 9 \text { - Soldier } \\
\text { major } \\
\text { Plate } 10 \text { - Soldier } \\
\text { minor }\end{array}$ \\
\hline
\end{tabular}


K.H.C.A. Wijerathna

\begin{tabular}{|c|c|c|c|c|c|c|c|c|c|}
\hline 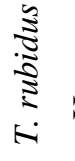 & 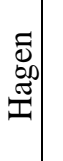 & ' & 1 & ' & ' & ' & ' & - & $\doteq$ \\
\hline$\frac{\widetilde{\Xi}}{\vdots}$ & 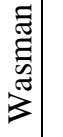 & $\stackrel{m}{=}$ & $n$ & $n$ & 6 & $n$ & $\nabla$ & $\sim$ & $\stackrel{\Sigma}{\curvearrowright}$ \\
\hline 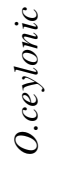 & $\hat{\jmath}$ & ' & ' & $N$ & ' & ' & - & - & $\frac{\kappa}{n}$ \\
\hline $\begin{array}{l}\widetilde{\Xi} \\
\vdots \\
z\end{array}$ & 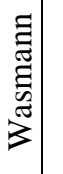 & ' & - & $n$ & ' & ' & ' & ' & $\bar{\lambda}$ \\
\hline$\dot{z}$ & 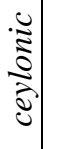 & $\nabla$ & $N$ & $m$ & ' & 1 & - & ' & $\stackrel{\curvearrowright}{\gamma}$ \\
\hline 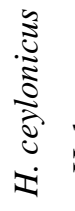 & 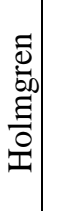 & - & - & $N$ & ' & ' & ' & ' & $\stackrel{\kappa}{m}$ \\
\hline$\dot{\theta}$ & 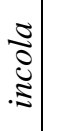 & 1 & - & - & ' & ' & - & ' & $\frac{\kappa}{m}$ \\
\hline 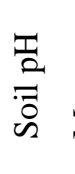 & 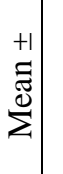 & 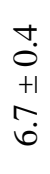 & \begin{tabular}{l}
$\sim$ \\
0 \\
+1 \\
\multirow{+}{*}{}
\end{tabular} & $\begin{array}{c}N \\
0 \\
+1 \\
0 \\
0\end{array}$ & $\begin{array}{l}n \\
0 \\
+1 \\
n \\
n\end{array}$ & $\begin{array}{l}+ \\
0 \\
+1 \\
\infty \\
0\end{array}$ & $\begin{array}{l}0 \\
\dot{0} \\
+1 \\
\dot{0} \\
\dot{0}\end{array}$ & $\begin{array}{l}\tilde{0} \\
+1 \\
n \\
n\end{array}$ & $\frac{0}{3}$ \\
\hline $\begin{array}{l}\bar{\delta} \\
\mathscr{2} \\
b^{\circ}\end{array}$ & 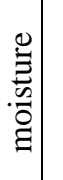 & $\begin{array}{l}0 \\
\stackrel{0}{+1} \\
+1 \\
\stackrel{+}{ \pm}\end{array}$ & 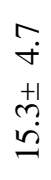 & $\begin{array}{l}\infty \\
\stackrel{\infty}{+1} \\
0 \\
0 \\
\end{array}$ & $\begin{array}{l}0 \\
\dot{r} \\
+1 \\
0 \\
\stackrel{r}{r}\end{array}$ & 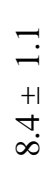 & $\begin{array}{l}+ \\
\stackrel{+}{*} \\
+1 \\
0 \\
\dot{0}\end{array}$ & $\begin{array}{l}\stackrel{+}{i} \\
+1 \\
\stackrel{\sim}{0} \\
\infty\end{array}$ & 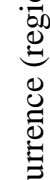 \\
\hline $\begin{array}{l}u \\
0 \\
= \\
\overline{0} \\
\text { is }\end{array}$ & $\begin{array}{l}a \\
\tilde{2} \\
+1 \\
\approx \\
\stackrel{\Xi}{\Sigma}\end{array}$ & $\begin{array}{l}0 \\
0 \\
+1 \\
m \\
n \\
0 \\
m\end{array}$ & $\begin{array}{l}0 \\
\stackrel{0}{+} \\
+1 \\
0 \\
\infty \\
\infty \\
\sim\end{array}$ & $\begin{array}{l}0 \\
\stackrel{0}{+} \\
+1 \\
0 \\
\infty \\
\stackrel{\infty}{N}\end{array}$ & $\begin{array}{l}0 \\
0 \\
+1 \\
m \\
\ddot{0} \\
\ddot{m}\end{array}$ & $\begin{array}{l}0 \\
\stackrel{+}{+1} \\
\stackrel{0}{0} \\
\stackrel{\lambda}{\mathrm{d}}\end{array}$ & $\begin{array}{l}\stackrel{0}{0} \\
+1 \\
\stackrel{+}{\circ} \\
\stackrel{\lambda}{d}\end{array}$ & $\begin{array}{l}n \\
+1 \\
m \\
\text { ஸे }\end{array}$ & $\begin{array}{l}0 \\
0 \\
4 \\
0 \\
0 \\
0 \\
0 \\
0\end{array}$ \\
\hline$\stackrel{\mathscr{C}}{\mathscr{n}}$ & & $\varangle$ & 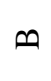 & $\cup$ & D & 피 & IL & $\circlearrowleft$ & \\
\hline
\end{tabular}




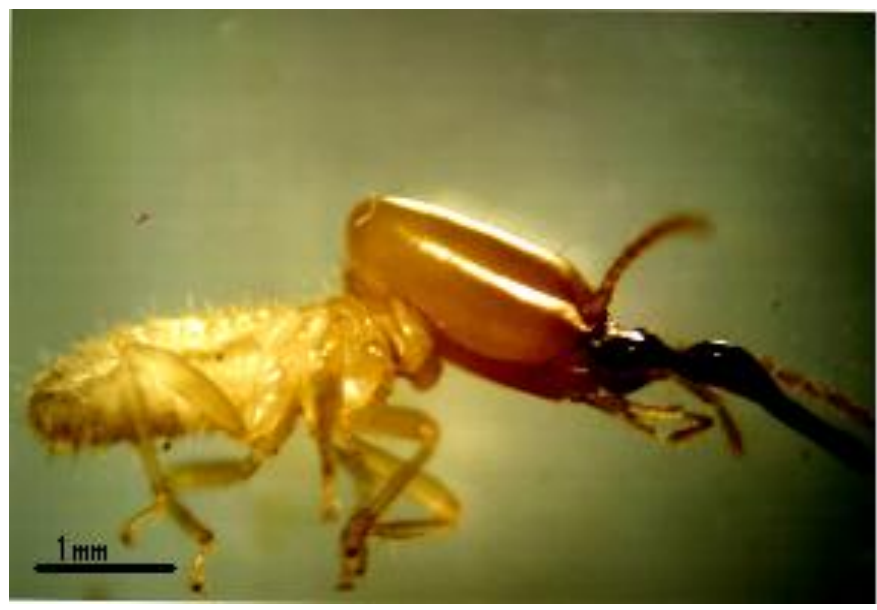

Plate 1: Dicuspeditermes incola: soldier

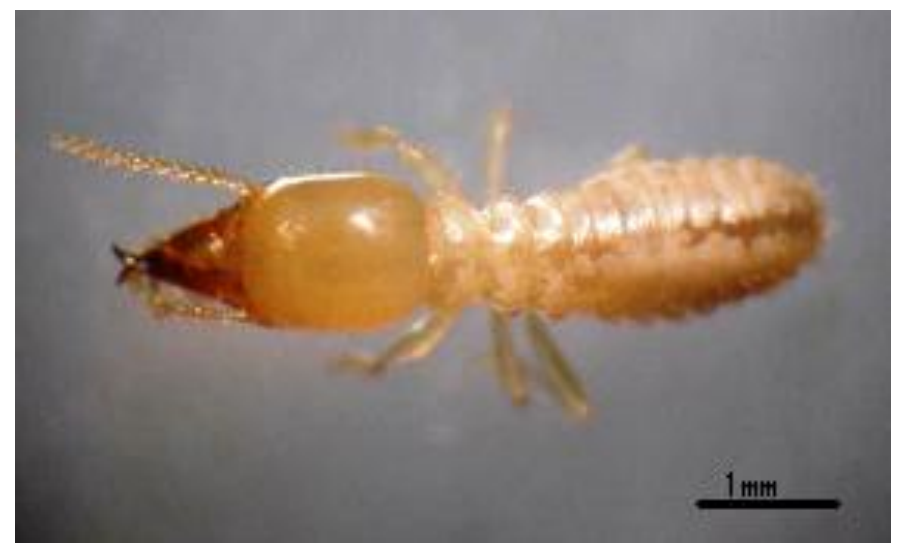

Plate 2: Heterotermes ceylonicus: soldier

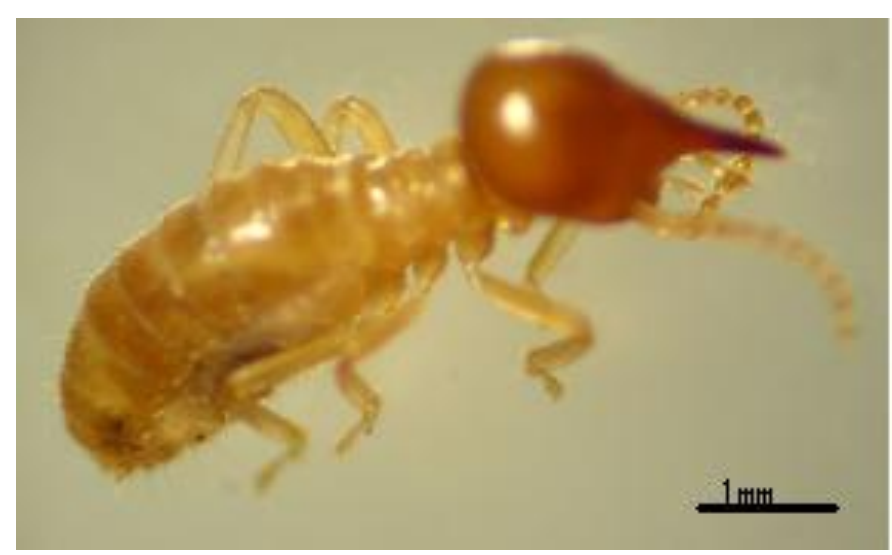

Plate 3: Nasutitermes ceylonicus soldier I 


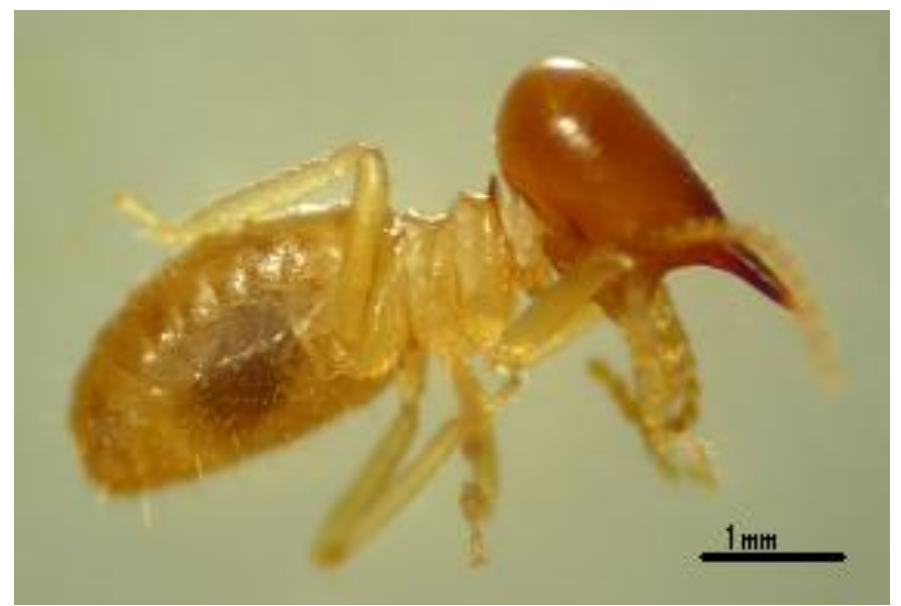

Plate 4: Nasutitermes ceylonicus soldier II

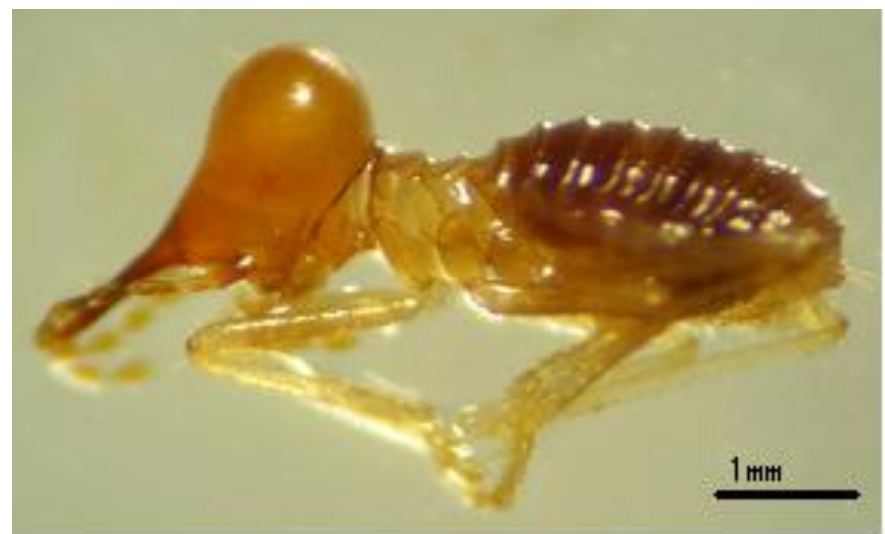

Plate 5: Nasutitermes horni soldier I

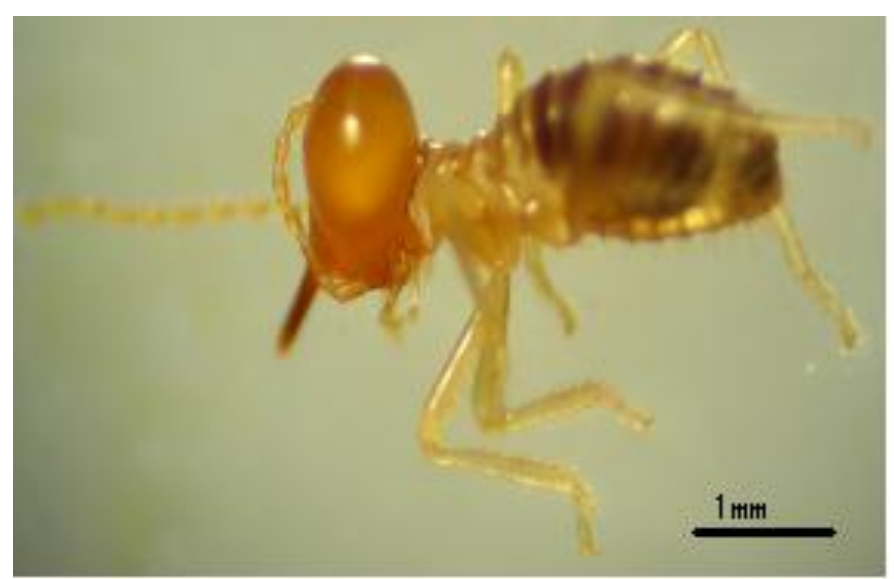

Plate 6: Nasutitermes horni soldier II 


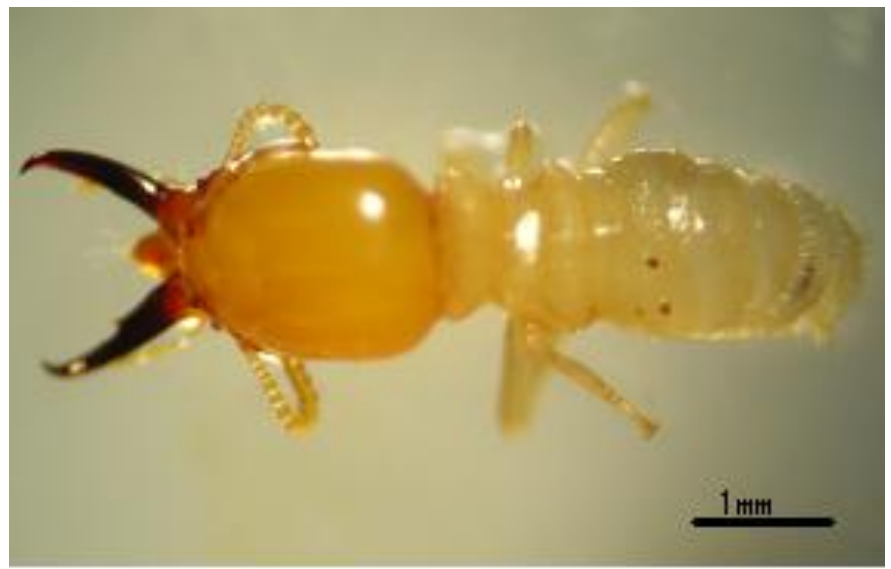

Plate 7: Odontotermes ceylonicus soldier

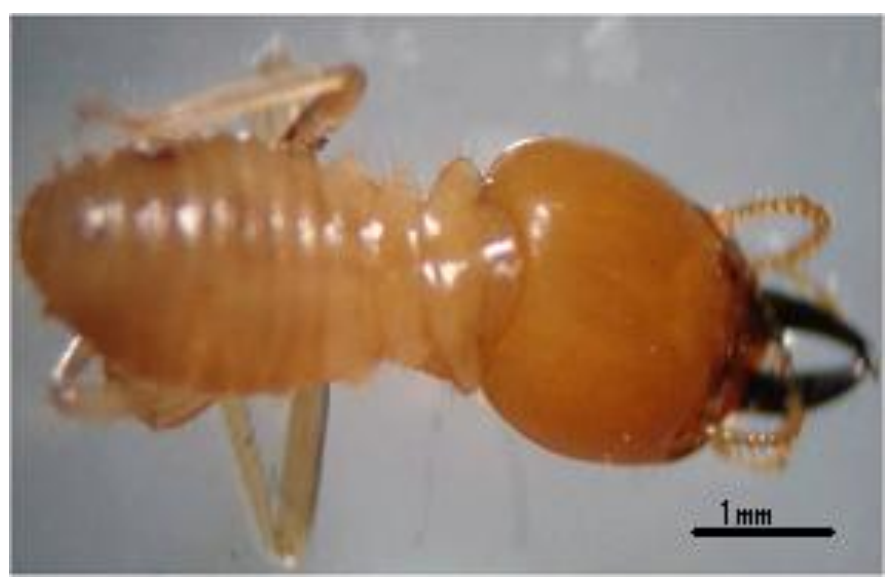

Plate 8: Odontotermes horni soldier

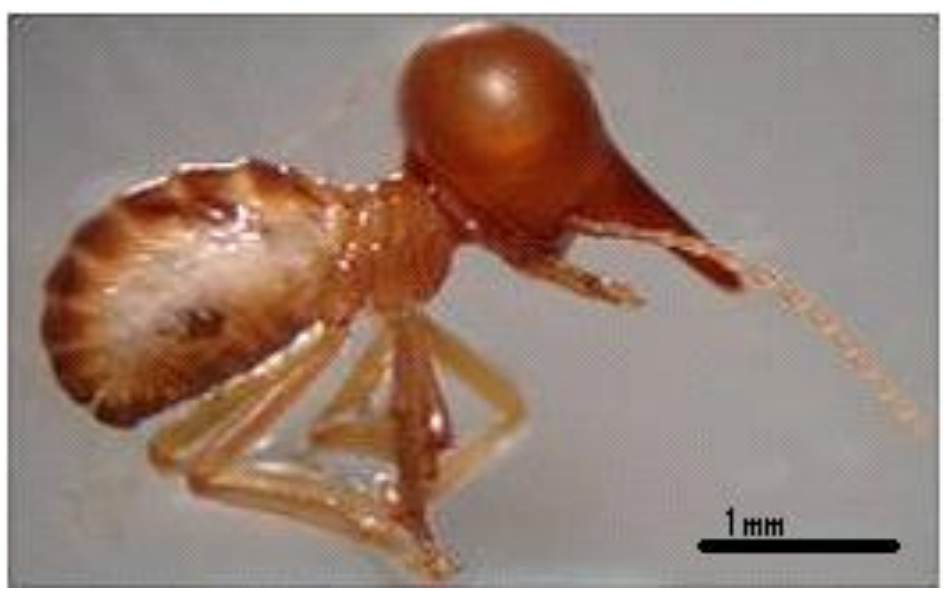

Plate 9: Trinervitermes rubidus: soldier I 


\section{K.H.C.A. Wijerathna}

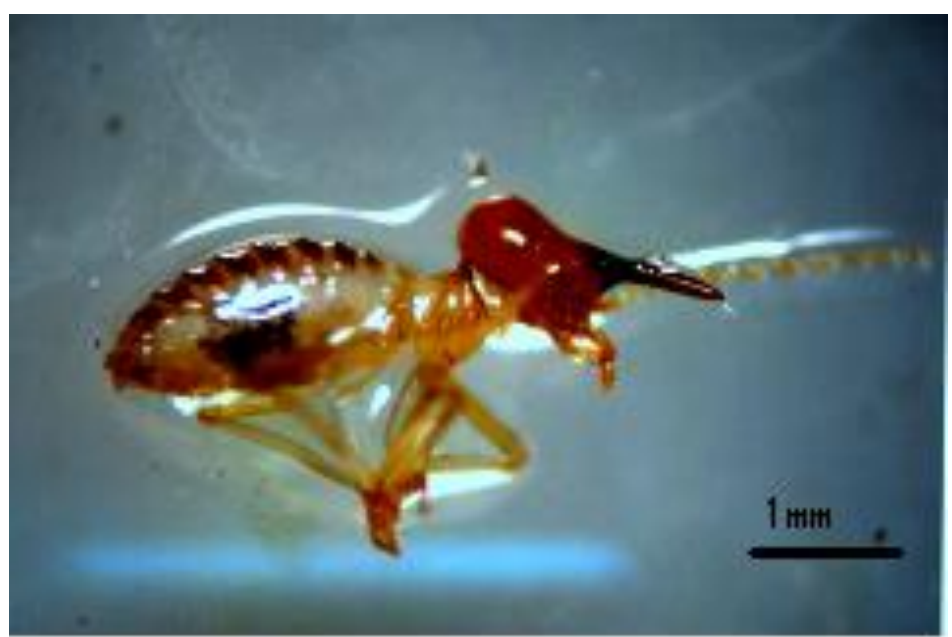

Plate 10: Trinervitermes rubidus: soldier II

\section{DISCUSSION}

Termite fauna at two different elevations of Hantane hills, Kandy consisted of the members of Termitidae only and the genera Nasutitermes, Dicuspiditermes and Odontotermes recorded there (Hemachandra et al. 2010) were also observed during the current survey. The two species, Odontotermes ceylonicus and $O$. horni were also present at Hantane hills showing their wide distribution in the country. The genus Ceylonitermellus recorded from Hantane hills was not found during this survey. The systematics of termites that inhabit other regions of Sri Lanka has not been well-documented and therefore these findings cannot be discussed with regard to any other similar survey conducted in Sri Lanka. Among the sampling methods used in this survey, soil sifting can be highly recommended for similar surveys to be conducted in the future and litter sifting method would also be useful when employed together with the sifting of soil (Table 2). Although termites could not be collected by keeping bait packs at indoor and outdoor locations, mud galleries observed in the bait packs indicated that termites had invaded them for a short period of time.

The preliminary inventory of termites (Table 4) has been prepared by sampling them for a relatively short period, from September, 2008 to April, 2009, due to the limited time period available, and this survey should be 


\section{A Preliminary Inventory of Subterranean Termites}

conducted at least throughout an year including both dry and rainy months in the future. Also, the survey of termites should be extended to other areas in the premises of University of Kelaniya and Sri Lanka (Kumarasinghe 2008). The reasons for the absence of the members of family Kalotermitidae during this survey are unknown.

Seven termite species recorded during the survey were not similarly distributed in the seven regions (Table 5) and $O$. horni showed a wide distribution because its larger size and the higher degree of sclerotization of the cuticle allow it to survive under wide ranges (Table 5) of environmental conditions (Pearce, 1999). Presence of Trinervitermes rubidus at a single location only should be due to its preference for lower soil moisture and lower $\mathrm{pH}$ existed at that region (Table 5).

Odontomachus simillimus is a very common ant species in the Science Faculty premises of University of Kelaniya (Dias 2006). Current results showed that this species may play a significant role in the natural control of $O$. ceylonicus in the area. Also, there is a possibility to use $O$. simillimus as a biological control agent of $O$. ceylonicus. Not only $O$. ceylonicus but also most of the subterranean termite species recorded from this survey act as pests of crops and human belongings.

Citronella oil and Neemazal-F can be used to control $O$. horni effectively and it will have an insignificant hazard to the environment. In addition, it will be less expensive when compared with the use of hazardous synthetic chemicals for control of this termite species (Kumarasinghe 2008). Field studies for the control of other termite species that are pests and encountered during current survey, should be conducted using citronella oil and Neemazal-F in the future for the confirmation of the findings of the laboratory investigation.

\section{ACKNOWLEDGEMENT}

Mr. Krishan Rajapakse is acknowledged for the photographing of termites. 


\section{REFERENCES}

Chhotani, O.B. 1997. The Fauna of India and the adjacent countries - Isoptera (Termites). Volume II, Zoological survey of India, Culcutta publications, India.

Dias, R.K.S. 2006. Overview of Ant research in Sri Lanka: 2000 - 2004. ANeT Newsletter No. 8: 7-10.

Harris, W.V. 1961. Termites, their recognition and control. Green and Co Ltd, London, U.K.

Pearce, M.J. 1999. Termites- Biology and Pest Management. CABI publishing, USA

Hemachandra, I.I. 2010. Distinctiveness of termite assemblages in two fragmented forest types in Hantane hills in the Kandy District of Sri Lanka. Ceylon Journal of Science (Bio. Sci.) 39, 1: 11 - 19.

Rathore, N.S. and Bhattacharyya, A.S. 2004. Termite (Insecta : Isoptera) Fauna of Gujarat and Rajastan - Present state of knowledge, Occasional papers Zoological survey of India, 233: 1 - 73.

Roonwal, M.L. and Chhotani, O.B. 1989. The Fauna of India and the adjacent countries- Isoptera (Termites). Volume I, Zoological survey of India, Culcutta publications, India.

Taylor, H.S., Mackay, W.P., Herrick, J.E., Gurrero, R.A. and Whitford, W.G. 1998. Comparison of field methods to detect termite activity in the northern Chihuahuan desert (Isopteran). Sociobiology 32:1-15.

Thakur, M.L. 2000. Forest entomology - ecology and management. SAI publishers, Dehra Dun.

Wijesekara, R.O.B. 1973. The chemical composition and analysis of Citronella oil. Journal of the National Science Council of Sri Lanka 1: 67-81.

Kumarasinghe, N.C. 2008. Present status of Termite research in Sri Lanka. Proceedings of the Mini Symposium on Social insects and their economic importance \& conservation : $15-26$. 